JIPFRI, Vol. 5 No. 1 JIPFRI (Jurnal Inovasi Pendidikan Fisika dan Riset IImiah)

Halaman: 9-20

Mei 2021 https://doi.org/10.30599/jipfri.v5i1.852

JIPFRI $)$ \%

\title{
Analisis Kemampuan Self Regulation Siswa pada Pembelajaran Sains saat PJJ Online di Era Pandemi Covid-19
}

\author{
Novalina Setyaningrum ${ }^{1 *}$, Bibin Rubini ${ }^{2}$, dan Didit Ardianto ${ }^{3}$ \\ 1,2,3 Universitas Pakuan Bogor \\ Jl. Pakuan, RT.02/RW.06. Kota Bogor \\ "E-mail: novalina.072619011@unpak.ac.id
}

\begin{abstract}
Abstrak
Penelitian ini bertujuan untuk mengetahui kemampuan self regulation siswa saat Pembelajaran Jarak Jauh (PJJ) online pada era pandemi Covid-19 sebuah SMA islam swasta di Kabupaten Karawang, Provinsi Jawa Barat. Penelitian ini dilaksanakan dengan metode deskriptif menggunakan teknik pengambilan data yaitu survei melalui Google Form dengan subjek penelitian adalah siswa kelas X, XI, XII. Hasil penelitian menunjukkan bahwa kemampuan self regulation siswa saat PJJ online di era pandemi covid-19 berada pada kategori tinggi $17 \%$, kategori sedang $69 \%$ dan kategori rendah $14 \%$. Jika dilihat pada masing-masing komponen self regulation maka mayoritas siswa berada pada kategori sedang (kognitif $66 \%$, perilaku $62 \%$ dan motivasi $50 \%$ ). Analisis juga dilakukan untuk mengukur kemampuan self regulation siswa saat sebelum, sedang dan setelah PJJ online yang ternyata mayoritas siswa berada pada kategori sedang yaitu preparation $76 \%$, implementation $53 \%$ dan reflection $64 \%$.
\end{abstract}

Kata kunci: Self Regulation, PJJ online, Covid-19

\begin{abstract}
This study aims to determine students' self regulation during the Covid-19 pandemic at islamic senior high school in Kabupaten Karawang, West Java. The research method used descriptive method and data collection techniques using a survey through Google Form. The research subjects were Grade X,XI,XII . The results showed that the skil of students' self regulation was in the high category with presentage of $17 \%$, medium category $69 \%$ and high catogory $14 \%$. Based on three components of self-regulation, majority of students were in medium category (cognitive $66 \%$, behavior $62 \%$ dan motivation 50\%). Analysis also have done to measure the skill of students' self regulation before and after online learning. Majority of the students were ini medium category (preparation $76 \%$, implementation $53 \%$, reflection $64 \%$ ). The result of the reasearch show that the students need more effort to enhance the skill of selt regulation, to be success in online learning.
\end{abstract}

Keywords: Self-regulated learning, Online learning, Covid-19

\section{PENDAHULUAN}

Saat ini pandemi Covid-19 merupakan krisis kesehatan terbesar yang sedang dihadapi oleh seluruh dunia (Ahorsu et al., 2020; Pan, 2020; Salzberger, Glück, \& Ehrenstein, 2020). Wabah ini dimulai dari Wuhan, China (Tian et al., 2020). Covid-19 tidak hanya memengaruhi ekonomi dan politik di berbagai negara tetapi juga sangat memengaruhi dunia pendidikan. Berbagai negara telah menerapkan kebijakan lockdown atau karantina dan social distancing atau pembatasan sosial. Menurut Perserikatan Bangsa-Bangsa (PBB), pendidikan merupakan salah satu sektor yang begitu terdampak oleh virus corona dalam waktu yang cepat dan skala yang amat luas. Berdasarkan data Organisasi PBB yang menangani Pendidikan, Keilmuan, dan Kebudayaan (UNESCO), ada lebih dari 850 juta siswa di seluruh dunia tidak belajar di sekolah dengan tujuan untuk menangkal penyebaran Covid-19 yang semakin meluas.

Pandemi Covid 19 yang tengah dihadapi saat ini turut mengubah dunia pendidikan, mulai dari kurikulum, proses pembelajaran, sistem 
penilaian, sarana prasarana pendukung hingga anggaran dana pendidikan. Hal ini merupakan sebuah tantangan terbesar yang dihadapi sistem pendidikan di seluruh dunia Metamorfosis ini membutuhkan adaptasi dari semua pihak, baik yang terlibat secara langsung (guru, siswa dan orang tua) maupun tidak langsung (stake holder bidang pendidikan). Pada masa transisi ini penerapan teknologi informasi di bidang pendidikan menjadi suatu hal yang sangat penting namun tidak mudah untuk dilaksanakan karena memerlukan waktu, pembiasaan, pengalaman dan beberapa faktor pendukung lainnya. Kemampuan guru dalam mengintegrasikan teknologi dalam pembelajaran di kelas dan kemandirian siswa dalam berinteraksi dengan teknologi merupakan faktor pendukung yang sangat penting.

Institusi pendidikan harus mengganti sistem belajar tatap muka dengan pembelajaran online dan pendidikan virtual tanpa persiapan apapun. Tidak adanya tatap muka dan minimnya interaksi antara guru dan siswa tengah menjadi bahan diskusi di berbagai riset (Voghoei et al., 2020). Selama pandemi ini siswa belajar dari rumah, baik secara Daring (dalam jaringan) atau online maupun Luring (luar jaringan) atau offline. Namun sebagian besar siswa di perkotaan belajar secara online baik secara sinkronus maupun asinkronus.

Pada pendekatan sinkronus online, interaksi antara guru dan siswa terjadi di tempat yang berbeda pada waktu yang bersamaan. Sedangkan pada pendekatan asinkronus online interaksi antara guru dan siswa terjadi di tempat yang berbeda dalam waktu yang belum tentu sama. Pembelajaran dilakukan dengan menggunakan website, media sosial hingga teleconference (Elleithy \& Sobh, 2014; Golitsyna, 2017). Pembelajaran berbasis online atau e-learning banyak dikombinasikan dengan berbagai media sosial (Blaschke, 2014), dan menurut beberapa penelitian memang dapat meningkatkan kemampuan siswa (Caird \& Hallett, 2019; Runhaar et al., 2019; Sahronih et al., 2019; Sutter \& Smith, 2017).

Kepala institusi harus dapat mengelola konsekuensi yang terjadi di dalam bidang pendidikan ini (Daniel, 2020). Selanjutnya menurut Daniel (2020), pembelajaran yang fleksibel dapat mewakili perubahan paradigma saat ini tidak hanya pada siswa tetapi juga guru, administrasi, teknisi, staf pelayanan dan institusi. Guru harus terbiasa mengintegrasikan teknologi dalam kelasnya ketika mengajar serta guru pun masih bingung dalam menentukan metode pembelajaran yang cocok ketika mengajar secara online.

Penggunaan teknologi dalam belajar online menjadi permasalahan tersendiri bagi siswa. Meskipun siswa di perkotaan sudah tidak asing lagi dalam menggunakan teknologi dalam kehidupan sehari-hari, misalnya untuk bermain "game online", berbelanja online, dan berinteraksi di berbagai media sosial. Ternyata hal ini belum tentu menunjukkan bahwa siswa memiliki kemampuan dalam literasi melalui teknologi. Hal ini terjadi karena kurangnya kemandirian dan kemampuan self regulation (regulasi diri) siswa dalam belajar tanpa didampingi guru secara langsung. Padahal hal tersebut adalah penentu kesuksesan siswa saat belajar online. Mengingat pentingnya self regulation siswa dalam pembelajaran online, maka guru harus dapat berperan aktif dalam meningkatkan self regulation dalam pembelajaran. Self regulation merupakan kemampuan yang penting dalam pendidikan karena dapat memengaruhi motivasi, proses pembelajaran, hasil belajar siswa dan peningkatan prestasi akademik (Xie, Hensley, Law, \& Sun, 2019). Self regulation merupakan kemampuan siswa untuk memikirkan diri sendiri, untuk menentukan tujuan pribadi dan untuk mengembangkan hasil belajar masing-masing (Andrade \& Heritage, 2017). Menurut pendapat lain, self regulation merupakan kemampuan memonitoring, mengarahkan dan mengatur diri sendiri untuk mencapai peningkatan proses pencapaian tujuan pembelajaran yang diinginkan (Brooks, Carroll, Gillies, Hattie, \& Gillies, 2019) . Schunk (2011) berpendapat bahwa idealnya proses self regulation terdiri dari proses menerapkan metode untuk mendapatkan hasil yang diharapkan, untuk dipadukan menjadi instruksi yang spesifik sehingga siswa dapat memahami bagaimana mengembangkan cara belajar, meningkatkan pemahaman dan membuat antisipasi dalam belajar. Self regulation siswa juga berhubungan dengan kepedulian 
siswa terhadap capaian tujuan pribadi yang diikuti oleh level pengaturan dan kualitas refleksi diri (Odinokaya, Krepkaia, Karpovich, \& Ivanova, 2019). Berdasarkan uraian di atas dapat disimpulkan bahwa self regulation adalah kemampuan seseorang untuk menentukan tujuan pribadi melalui kegiatan monitoring, mengarahkan, mengatur diri sendiri dan mengevaluasi proses yang telah dilakukan sehingga dapat meningkatkan pemahaman diri untuk mencapai tujuan yang diharapkan.

Pembelajaran sains yang efektif tidak hanya fokus pada pengembangan proses pembelajaran saja tetapi juga dapat mengembangkan self regulation siswa pada komponen metakognitif sebagai kecakapan hidup untuk meraih sukses pada level pembelajaran sains yang lebih tinggi untuk membangun konsep pengetahuan dan strategi prosedural (Schraw, Crippen, \& Hartley, 2006)

Self regulation memiliki enam komponen yaitu : 1) Kognitif, 2) Perilaku, 3) Motivasi, 4) Emosi, 5) Sosial, 6) Lingkungan (Schunk, 2011). Siswa yang memiliki self regulation yang baik akan lebih sukses dalam belajar secara online (Daniela, 2015). Upaya peningkatan self regulation tentunya akan lebih efektif jika terdapat informasi terkait dengan kemampuan self regulation yang dimiliki siswa. Pada penelitian ini komponen self regulation yang dianalisis adalah kognitif, perilaku dan motivasi (Schunk, 2011) pada kondisi sebelum PJJ online (preparation), saat pelaksanaan PJJ online (implementation) dan setelah pelaksanaan PJJ online (reflection).

Penelitian ini bertujuan untuk menganalisis kemampuan self regulation secara umum, menganalisis kemampuan self regulation pada komponen kognitif, perilaku dan motivasi serta untuk mengidentifikasi implementasi kemampuan self regulation pada periode sebelum PJJ online (preparation), saat pelaksanaan (implementation) dan setelah pelaksanaan PJJ online (reflection) yaitu pembelajaran mandiri secara offline.

\section{METODE}

Penelitian dilaksanakan pada semester satu tahun ajaran 2020/2021, tepatnya di bulan Juli-Desember 2020. Penelitian ini dilaksanakan pada pembelajaran Fisika, Kimia dan Biologi dengan metode deskriptif menggunakan teknik pengambilan data yaitu survei. Penelitian ini dilaksanakan di sebuah SMA islam swasta di Kabupaten Karawang, Provinsi Jawa Barat. Subjek penelitian dalam penelitian ini adalah siswa kelas X, XI dan XII yang berjumlah 174 siswa. Instrumen yang dibuat berupa angket secara online menggunakan google formulir mengenai kemampuan self regulation siswa saat Pembelajaran Jarak Jauh (PJJ online) di era pandemi Covid-19. Instrumen di sebar melalui media sosial.

Instrumen terdiri dari 5 bagian, 1) Respon siswa terkait PJJ online secara umum, (2) Respon siswa terkait kemampuan self regulation komponen Kognitif, (3) Respon siswa terkait kemampuan self regulation komponen Perilaku, (4) Respon siswa terkait kemampuan self regulation komponen Motivasi, 5) Respon guru dalam mengajar sains saat PJJ online. Instrumen pertama terkait respon terhadap tingkat pemahaman siswa terhadap materi pembelajaran yang dikaitkan dengan penggunaan berbagai media pembelajaran, baik menggunakan pendekatan sinkronus online, asinkronus online maupun kombinasi keduanya. Instrumen kedua merupakan sebuah instrumen terkait dengan kemampuan self regulation pada komponen kognitif yang terdiri dari 7 pernyataan positif. Instrumen ketiga adalah instrument yang terkait dengan kemampuan self regulation pada komponen perilaku yang terdiri dari 8 pernyataan positif. Sementara itu, instrumen keempat berisi respon siswa terkait dengan kemampuan self regulation pada komponen motivasi yang terdiri dari dua pernyaatan positif. Pada instrumen kedua, ketiga dan keempat ini opsi jawaban memiliki skor tertinggi yaitu 2 yang menunjukkan tingginya kemampuan self regulation dan skor terendah adalah 0 yang menunjukkan belum ada kemampuan self regulation. Sedangkan instrumen terakhir merupakan respon guru sains terkait dengan pendekatan (sinkronus, asinkronus, kombinasi) dan media yang digunakan ketika mengajar sains serta identifikasi permasalahan terbesar siswa saat PJJ online.

Analisis data yang digunakan dalam penelitian ini adalah dengan mendeskripsikan berbagai hasil penelitian tersebut dalam bentuk presentase. Hal ini untuk melihat presentase 
kemampuan self regulation siswa baik secara umum maupun berdasarkan komponen kognitif, perilaku dan motivasi. Selain itu juga dianalisis distribusi kemampuan self regulation pada saat persiapan (preparation), saat belajar (Implementation) dan saat setelah selesai PJJ online (reflection). Kategori Tinggi, Rendah, dan Sedang ditentukan dengan mencari terlebih dahulu rerata skor dan Standar Deviasi (SD) seperti perhitungan sebagai berikut :

1. Rendah : $\mathrm{x}<$ (rata-sata skor - 1SD)

2. Sedang : (rata-sata skor-1 SD) $\leq x<\quad$ (ratasata skor + 1 SD)

3. Tinggi $: x>$ (rata-sata skor $+1 \mathrm{SD})$

Hasil analisis data disajikan dalam bentuk tabel dan grafik, untuk memudahkan melihat presentase tertinggi dan terendah dari jawaban siswa dan presentase kemampuan self regulation pada kategori tinggi, rendah dan sedang.

\section{HASIL DAN PEMBAHASAN}

\section{Self Regulation}

Hasil dari penelitian ini menunjukkan bahwa sebagian besar siswa memiliki kemampuan self regulation pada kategori sedang, baik dilihat dari kemampuan self regulation secara umum maupun pada tiap komponen (kognitif, perilaku dan motivasi). Selain itu, hasil penelitian ini juga menunjukkan bahwa sebagian siswa siswa memiliki kemampuan self regulation pada kategori sedang jika dilihat dari implementasi pelaksanaan PJJ online yang terdiri dari preparation, implementation dan reflection.

Pada awal penelitian dilakukan pengukuran respon siswa terkait dengan kemampuan siswa dalam memahami materi dan penggunaan beberapa media e-learning saat PJJ online. Sebagian besar siswa lebih memahami materi saat belajar secara tatap muka $(82,9 \%)$ jika dibandingkan dengan belajar secara online maupun offline (melalui radio, TV, penugasan). Ketika digali informasi lebih dalam terkait pembelajaran online, $48,6 \%$ siswa menjawab lebih memahami pembelajaran secara tatap maya melalui Zoom/ Wa video call /Google meet/Webex, 34, \% siswa bisa memahami materi melalui WA grup/ Google classroom/Edmodo dll karena masih bisa langsung berkomunikasi dengan guru meskipun tidak bertatap muka secara online dan 16,5\% siswa dapat memahami materi melalui semua media. Terkait pembelajaran dengan pendekatan asinkronus online melalui LMS, ternyata sebagian besar siswa $(77,7 \%)$ tidak selalu memahami materi yang diberikan.

Setelah diawali dengan pengukuran respon siswa terkait pemahaman materi pada saat PJJ online, dilakukan pengukuran respon siswa terhadap kemampuan self regulation secara keseluruhan. Terdapat 17 pertanyaan, dengan skor terendah adalah 6 dan skor tertinggi adalah 33. Untuk menentukan kategori rendah, sedang dan tinggi, terlebih dahulu ditentukan rata-rata skor $(21,82)$ dan 1 Standar Deviasi $(5,28)$. Dengan demikian diperoleh skala kategori Self Regulation seperti pada tabel di bawah ini :

Tabel 1. Kategori Kemampuan Self Regulation

\begin{tabular}{ll} 
& Siswa \\
\hline Kategori & Skala \\
\hline Rendah & $\mathrm{x}<16$ \\
Sedang & $16 \leq \mathrm{x}<27$ \\
Tinggi & $\mathrm{x} \geq 27$ \\
\hline
\end{tabular}

Hasil penelitian menunjukkan bahwa mayoritas siswa $(69 \%)$ berada pada kategori sedang, dan hanya $17 \%$ siswa yang berada pada katgori tinggi dan $14 \%$ pada kategori rendah. hasil penelitian selengkapnya dapat dilihat pada gambar 1 .

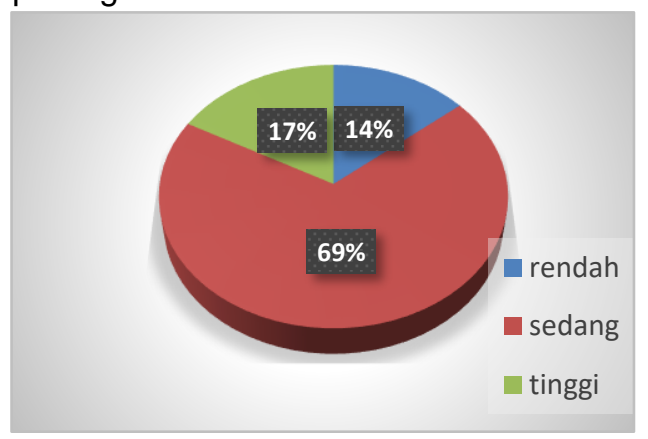

Gambar 1. Presentase Kemampuan Self Regulation Siswa

\section{Kognitif}

Selain menganalisis kemampuan Self Regulation siswa secara menyeluruh, penelitian ini juga menganalisis bagaimana kemampuan Self Regulation pada masing-masing komponen yaitu kognitif, perilaku dan motivasi. Sebagian besar kemampuan self regulation siswa berada pada kategori sedang. Penjelasan hasil terdapat pada tabel 2. 
Tabel 2. Kategori Kemampuan Self Regulation Siswa

\begin{tabular}{|c|c|c|c|}
\hline \multirow{2}{*}{$\begin{array}{l}\text { Komponen } \\
\text { Self } \\
\text { Regulation }\end{array}$} & \multicolumn{3}{|c|}{$\begin{array}{l}\text { Persentase Kemampuan } \\
\text { Self Regulation }\end{array}$} \\
\hline & $\begin{array}{l}\text { Rendah } \\
\text { (\%) }\end{array}$ & $\begin{array}{l}\text { Sedang } \\
(\%)\end{array}$ & $\begin{array}{l}\text { Tinggi } \\
(\%)\end{array}$ \\
\hline & 12 & 66 & 22 \\
\hline & 16 & 62 & 22 \\
\hline & & 50 & 42 \\
\hline
\end{tabular}

Dari 17 pernyataan yang diberikan kepada responden, terdapat 7 pernyataan yang termasuk pada komponen kognitif, yaitu:

1. Di awal pembelajaran, saat guru menyampaikan tujuan pembelajaran, saya :
a. Selalu memperhatikan (2)
b. Kadang-kadang memperhatikan (1)
c. Tidak memperhatikan, yang penting mengikuti pembelajaran. (0)

2. Jika saya menerima tugas yang saya tidak mengerti :
a. Saya akan selalu menanyakan kembali kepada guru sebelum saya menanyakan tugas (2)
b. Kadang-kadang saya menanyakan kepada guru (1)
c. saya tetap mengerjakan walaupun saya tidak mengerti $(0)$

3. Saya mengecek kembali pekerjaan saya saat menyelesaikan tugas
a. Selalu (2)
b. Kadang-kadang (1)
c. Jarang (0)

4. Dalam proses mengerjakan tugas, saya mencoba mengecek kebenaran jawaban.
a. Selalu (2)
b. Kadang-kadang (1)
c. Saya hanya mengecek jika yakin telah melakukan kesalahan $(0)$

5. Jika saya ragu terhadap pemahaman makna pada materi berupa teks bacaan, saya akan:
a. Membaca kembali teks bacaan yang belum saya mengerti (2)
b. Kadang-kadang saya membaca lagi (1)
c. Saya lanjut membaca teks bacaan lainnya (0)

6. Kesalahan saat mengerjakan tugas seharusnya saya perbaiki, :
a. Jika ada seseorang yang menemukan kesalahan saya saja (0)
b. Kadang-kadang saja (1)
c. Secara langsung (2)

7. Saat mengerjakan tugas, saya puas jika mengerjakan secara detail dan benar.
a. Jarang, karena saya lebih suka menjawab secara singkat (0)
b. Kadang-kadang, karena tergantung pada pemahaman saya terhadap soal (1)

C. Selalu, karena saya akan berusaha
mencari informasi dari berbagai sumber (2)

Informasi yang didapatkan dari hasil respon siswa yaitu skor terendah siswa adalah 2 dan skor tertinggi 14. Hasil penelitian menunjukkan beragamnya respon siswa terkait dengan kemampuan self regulation siswa pada komponen kognitif ini. Terdapat $57,1 \%$ siswa yang memperhatikan tujuan pembelajaran yang disampaikan oleh guru, sedangkan siswa lain hanya kadang-kadang saja memperhatikan dan beberapa siswa hanya sekedar mengikut kegiatan pembelajaran. Hasil penelitian selengkapnya terdapat pada tabel 3 .

Tabel 3. Persentase respon siswa pada kemampuan self regulation komponen kognitif

\begin{tabular}{clll}
\hline No Pernyataan & \multicolumn{3}{c}{ Persentase Respon } \\
& A & B & C \\
\hline 1 & 57,1 & 40,6 & 1,7 \\
2 & 18,9 & 64 & 17,1 \\
3 & 56 & 39,4 & 4,6 \\
4 & 49,7 & 34,9 & 15,4 \\
5 & 74,1 & 22,9 & 4 \\
6 & 26,3 & 27,4 & 46,3 \\
7 & 7,4 & 59,5 & 33,1 \\
\hline
\end{tabular}

Penentuan kategori (rendah, sedang dan tinggi) diawali dengan mencari rata-rata skor kuisioner terkait self regulation siswa. Kemudian dilanjutkan dengan menghitung Standar Deviasi (SD) melalui program Excel. Perhitungan penentuan kategori dapat dilihat pada tabel 4. 
Tabel 4. Perhitungan Kategori Self Regulation

\begin{tabular}{ll}
\hline \multicolumn{1}{c}{ Kategori } & \multicolumn{1}{c}{ Perhitungan } \\
\hline Rendah & $\mathrm{x}<$ (rata-rata skor $-1 \mathrm{SD})$ \\
\hline Sedang & $($ rata-rata skor $-1 \mathrm{SD}) \leq \mathrm{x}<$ \\
& (rata-rata skor $+1 \mathrm{SD})$ \\
\hline Tinggi & $\mathrm{x}>$ (rata-rata skor $+1 \mathrm{SD})$ \\
\hline
\end{tabular}

Setelah mendapatkan hasil perhitungan pada kategori rendah, sedang dan tinggi, didapatkan hasil rata-rata skor adalah 9,61 dan hasil untuk 1 Standar Deviasi adalah 2,47. Selanjutnya dapat ditentukan skala kategori kemampuan self regulation siswa pada komponen kognitif seperti pada tabel 5 .

Tabel 5. Kategori Kemampuan Self Regulation Siswa Pada Komponen Kognitif

\begin{tabular}{ll}
\hline Kategori & Skala \\
\hline Rendah & $x<7$ \\
Sedang & $7 \leq x<12$ \\
Tinggi & $x \geq 12$ \\
\hline
\end{tabular}

Hasil penelitian ini menunjukkan bahwa persentase kemampuan Self Regulation siswa pada komponen kognitif ini, mayoritas berada pada kategori sedang (66\%). Hasil penelitian selengkapnya dapat dilihat pada gambar 2 .

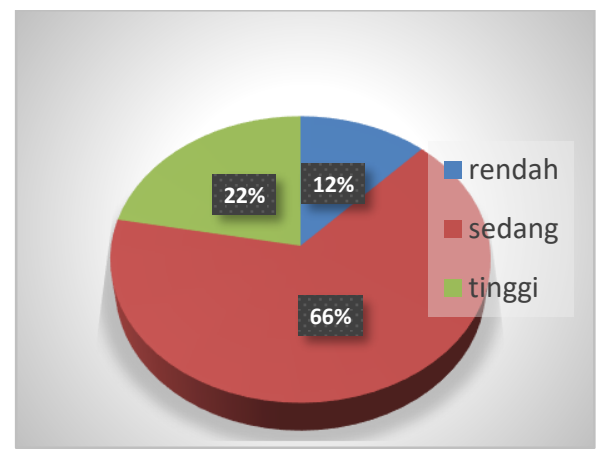

Gambar 2. Presentase Kemampuan Self Regulation pada komponen Kognitif

\section{Perilaku}

Berikutnya adalah penelitian terkait kemampuan self regulation siswa pada komponen perilaku. Dari 17 pernyataan yang diberikan kepada responden, terdapat 8 pernyataan yang terkait dengan komponen perilaku yaitu :

1. Saat akan PJJ online, saya membersihkan dan merapikan ruangan tempat saya belajar.
a. Selalu (2)
b. Kadang-kadang (1)
c. Langsung belajar (0)

2. Saat akan PJJ online, saya menyiapkan buku catatan dan buku paket.
a. Selalu (2)
b. Kadang-kadang (1)
c. . Jarang, saya langsung mengikuti kegiatan pembelajaran

3. Saat belajar secara online, saya terlebih dahulu mengondisikan keluarga di rumah (orang tua, kakak, adik) agar tidak mengganggu proses belajar.
a. Selalu (2)
b. Kadang-kadang
c. Jarang, saya langsung mengikuti kegiatan pembelajaran (0)

4. Media pembelajaran berupa video, ...

a. Hanya saya lihat saat jadwal PJJ online (0)

b. Saya lihat kembali jika saya merasa belum paham saja (1)

c. Saya lihat beberapa kali untuk menguatkan ingatan \& pemahaman

5. Jika mendapatkan nilai bagus, ...
a. Saya akan memberi penghargaan pada diri saya sendiri (2)
b. Saya merasa senang dan meminta hadiah dari orang tua( 1 )
c. Saya merasa biasa saja (0)

6. Jika mendapatkan nilai jelek, ...
a. Saya akan memberi hukuman pada diri saya sendiri berupa konsekuensi pengurangan waktu main HP (2)
b. Saya merasa sedih (1)
c. Saya merasa biasa saja $(0)$

7. Setelah melaksanakan PJJ online, saya selalu membereskan ruang belajar saya dan bersiap untuk jadwal PJJ online selanjutnya
a. Selalu (2)
b. Kadang-kadang (1)
c. Jarang, karena langsung istirahat (0)

8. Ketika saya merencanakan kegiatan, saya juga membuat ceklis kegiatan yang sudah dan belum dilakukan.
a. Selalu (2)
b. Kadang-kadang (1)
c. Jarang (0)

Dari hasil respon siswa didapatkan skor terendah adalah 0 dan skor tertinggi adalah 15 . 
Hasil penelitian terkait tingkat kemampuan self regulation pada komponen perilaku menggambarkan respon yang beragam. Hanya $36 \%$ siswa yang selalu membersihkan dan merapikan ruang belajar sebelum pelaksanaan PJJ online, sementara siswa lain kadang-kadang saja atau bahkan tidak melakukan pengondisian ruang belajar sebelum PJJ online. Hasil penelitian selengkapnya dapat dilihat pada tabel 6.

Tabel 6. Presentase respon siswa pada kemampuan self regulation komponen Perilaku

\begin{tabular}{clll}
\hline No & \multicolumn{3}{c}{ Presentase Respon } \\
Pernyataan & \multicolumn{1}{c}{ A } & \multicolumn{1}{c}{ B } & \multicolumn{1}{c}{ C } \\
\hline 1 & 36 & 50,3 & 13,7 \\
2 & 53,7 & 38,3 & 8 \\
3 & 38,9 & 34,9 & 26,3 \\
4 & 22,3 & 59,4 & 18,3 \\
5 & 69,7 & 26,9 & 3,4 \\
6 & 30,3 & 52 & 17,7 \\
7 & 41,1 & 36 & 22,9 \\
8 & 24 & 32 & 32 \\
\hline
\end{tabular}

Dengan cara perhitungan yang sama seperti Tabel 4, terlebih dahulu ditentukan ratarata skor $(9,11)$ dan 1 Standar Deviasi $(3,04)$, selanjutnya dapat ditentukan kategori rendah, sedang dan tinggi. Skala kategori kemampuan self regulation siswa pada komponen Perilaku seperti pada tabel 7 .

Tabel 7. Kategori Kemampuan Self Regulation Siswa Pada Komponen Perilaku

\begin{tabular}{ll}
\hline Kategori & Skala \\
\hline Rendah & $x<6$ \\
Sedang & $6 \leq x<12$ \\
Tinggi & $x \geq 12$
\end{tabular}

Dari hasil penelitian yang telah dilakukan ternyata persentase kemampuan Self Regulation siswa pada komponen perilaku berada pada kategori sedang (62\%). Hasil penelitian selengkapnya terdapat pada gambar 3.

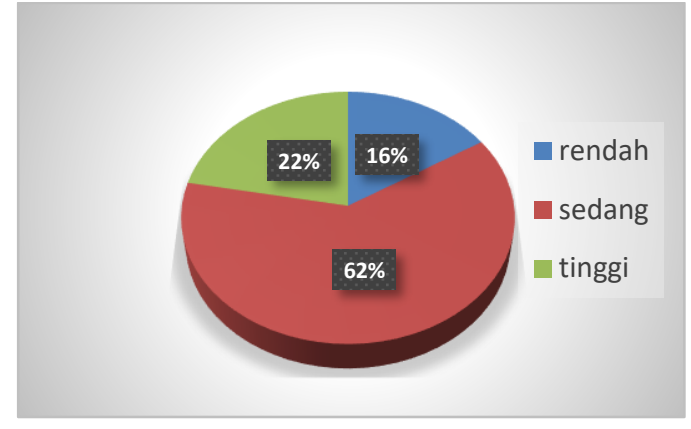

Gambar 3. Persentase Kemampuan Self Regulation Siswa pada Komponen Perilaku

Motivasi

Selanjutnya penelitian dilakukan untuk mengukur kemampuan Self Regulation pada komponen Motivasi. Hasil survei online menunjukkan bahwa persentase kemampuan Self Regulation siswa pada komponen motivasi ini siswa yang berada pada kategori tinggi $42 \%$, kategori sedang $50 \%$ dan kategori rendah $8 \%$. Hasil penelitian selengkapnya terdapat pada gambar 4.

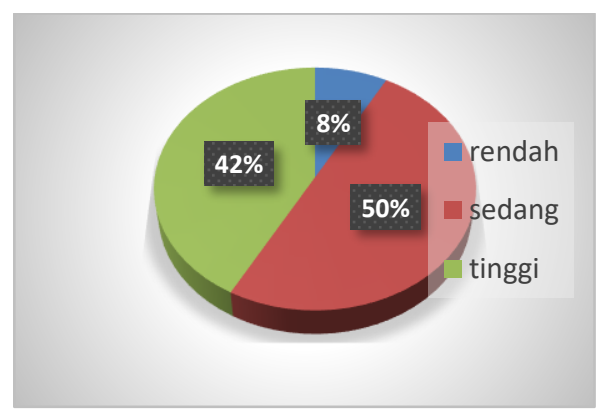

Gambar 4. Persentase Kemampuan Self Regulation Siswa pada Komponen Motivasi

Guru-guru sains menggunakan beberapa kombinasi media pembelajaran selama PJJ online. $100 \%$ guru pernah melakukan kombinasi Zoom \& LMS, WA \& LMS dan Zoom \& WA. Hanya $33,3 \%$ guru yang mengkombinasikan WA dan Instagram. Sementara 33,3\% guru menggunakan aplikasi lain seperti animasi dan virtual lab. Hasil lebih jelas terdapat pada Gambar 5 . 


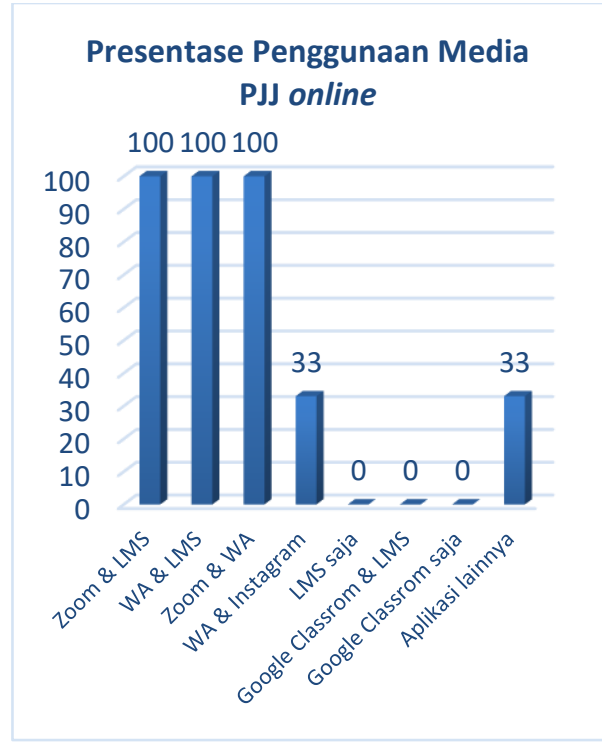

Gambar 5. Kombinasi media pembelajaran yang digunakan guru sains saat PJJ online

Terakhir terkait dengan kemampuan self regulation pada tahap preparation, implementation dan reflection. Hasil penelitian menunjukkan bahwa sebagian besar siswa berada pada kategori sedang. Hasil selengkapnya terdapat pada tabel 7 .

Tabel 8. Implementasi Kemampuan Self Regulation Siswa Saat PJJ Online

\begin{tabular}{|c|c|c|c|}
\hline \multirow{2}{*}{$\begin{array}{l}\text { Komponen } \\
\text { Self } \\
\text { Regulation }\end{array}$} & \multicolumn{3}{|c|}{$\begin{array}{l}\text { Presentase Kemampuan } \\
\text { Self Regulation }\end{array}$} \\
\hline & $\begin{array}{c}\text { Rendah } \\
(\%)\end{array}$ & $\begin{array}{c}\text { Sedang } \\
(\%)\end{array}$ & $\begin{array}{c}\text { Tinggi } \\
(\%)\end{array}$ \\
\hline & & 76 & \\
\hline Imple & 18 & 52 & 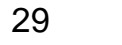 \\
\hline Reflection & 8 & 64 & 28 \\
\hline
\end{tabular}

Tidak semua komponen self regulation (kognitif, perilaku, motivasi) diterapkan pada ketiga tahap tersebut. Penerapan komponenkomponen self regulation dapat dilihat pada tabel 9.

Tabel 9. Penerapan Komponen Self Regulation Siswa

\begin{tabular}{lccc}
\hline & Kognitif & Perilaku & Motivasi \\
\cline { 2 - 4 } Preparation & - & $\sqrt{ }$ & $\sqrt{ }$ \\
Implementation & $\sqrt{ }$ & $\sqrt{ }$ & $\sqrt{ }$ \\
Reflection & $\sqrt{ }$ & $\sqrt{ }$ & $\sqrt{ }$ \\
\hline
\end{tabular}

\section{PEMBAHASAN}

Berdasarkan hasil penelitian ini dapat diperoleh hasil bahwa pembelajaran sains yang dilakukan di era pandemi covid-19 ini dilaksanakan dengan PJJ online. Meski sebagian besar siswa ternyata lebih memahami materi ketika pembelajaran tatap muka, PJJ online menjadi tantangan bagi guru-guru sains untuk bisa mengintegrasikan teknologi dalam kegiatan pembelajaran. Selain itu guru-guru sains juga dituntut untuk mengembangkan kreatifitas dalam mengkombinasikan beragam media pembelajaran online.

Pembelajaran sains yang dilaksanakan di era covid-19 ini dilakukan lebih fleksibel yaitu dilakukan secara kombinasi atau blended learning yang memadukan pembelajaran konvensional dengan materi online secara sistematis. Dapat juga dilakukan dengan menggabungkan satu model dengan model pembelajaran lainnya, seperti melakukan kombinasi antara pembelajaran sinkronus online dan asinkronus online (Zaka, 2013). Hasil penelitian menunjukkan bahwa guru-guru sains mengkombinasikan pendekatan sinkronus online dan asinkronus online. Kegiatan pembelajaran yang dilakukan dengan pendekatan sinkronus online dapat berupa diskusi di grup Whatsapp, pertemuan di Zoom dan penggunaan aplikasi pembelajaran online seperti mikroskop virtual ( magnifier and microscope) untuk mata pelajaran biologi dan chemsketch pada materi senyawa hidrokarbon mata pelajaran kimia. Untuk layanan konsultasi belajar, digunakan video conference/video call.

Pendekatan asinkronus online dilakukan melalui e-learning yang menggunakan Learning Management System (LMS) berbasis MOODLE. Dengan adanya LMS ini siswa akan lebih fleksibel ketika belajar, karena siswa dapat mengakses materi pembelajaran kapan saja dan dimana saja. Guru hanya mengatur waktu pengumpulan tugas dalam sistem pada LMS tersebut. Guru memberikan kesempatan bagi siswa untuk menyelesaikan pembelajaran di LMS (literasi, pemahaman materi dan penyelesaian tugas) dalam waktu tiga hari. Hal ini merupakan solusi ketika siswa mengalami Kendal sinyal pada saat jadwal belajar yang ditetapkan sekolah.

Guru diberi kesempatan untuk kreatif memilih pendekatan pembelajaran dan kegiatan pembelajaran pada tiap pertemuan. Beberapa guru memilih untuk mengkombinasikan zoom dan LMS, whatsapp dan LMS, Zoom dan 
whatsapp serta whatsapp dan Instagram. Kombinasi media pembelajaran online ini disesuaikan dengan materi yang akan disampaikan ke siswa. Tujuannya adalah menyajikan pembelajaran sains secara online yang menarik, dapat dipahami siswa dan tidak membosankan. Karena kombinasi ini dilaksanakan berbeda-beda pada tiap pertemuan.

Pada awal pembelajaran siswa wajib mengisi presensi online terlebih dahulu setelah itu baru mengikuti pembelajaran, baik secara sinkronus online maupun asinkronus online. Hal ini bertujuan untuk melatih kedisiplinan dan kemandirian siswa saat belajar secara online. Siswa harus mampu belajar secara mandiri tanpa didampingi guru secara langsung. Kemampuan self regulation siswa menjadi sangat penting dan menjadi kunci sukses siswa saat PJJ online (Kuo, Tseng, \& Kuo, 2020). Beberapa penelitian menyimpulkan bahwa self regulation memiliki hubungan dengan perilaku pembelajaran secara individual dan keefektifan pelaksanaannya (Lin, Huang, \& Chuang, 2015).

Hasil penelitian menunjukkan bahwa mayoritas siswa memiliki kemampuan self regulation yang berada pada kategori sedang. Untuk siswa yang termasuk kategori rendah memang cukup sulit mengikuti PJJ online. Hal ini terlihat dari kedisiplinan yang rendah ketika harus mengisi presensi online sebelum pembelajaran dan ketuntasan dalam menyelesaikan tugas. Siswa-siswa itu membutuhkan perhatian dan bimbingan secara langsung untuk dapat mengikuti PJJ online. Upaya yang dilakukan pihak sekolah adalah dengan mengkomunikasikan masalah ini dengan orang tua, mendatangi rumah siswa dan memberikan undangan agar siswa datang ke sekolah untuk mendapatkan bimbingan langsung dari guru. Hal ini menunjukkan memang perlu adanya upaya peningkatan self regulation dalam belajar secara online.

Komponen kognitif secara spesifik terdiri dari kegiatan mengoperasikan informasi yang telah diperoleh, dimanipulasi dan digunakan dalam proses pembelajaran (Hooshyar, Kori, Pedaste, \& Bardone, 2019). Komponen kognitif merupakan kemampuan belajar yang mengarah pada strategi pemikiran, strategi pemecahan masalah dan kemampuan berpikir kritis (Schraw, Crippen, \& Hartley, 2006). Hasil penelitian ini menunjukkan bahwa mayoritas siswa memiliki kemampuan Self Regulation pada komponen kognitif pada kategori sedang. Hal ini berarti siswa masih perlu belajar bagaimana strategi memperoleh informasi, mengolah informasi dan menggunakan informasi yang berupa materi pembelajaran secara efektif agar informasi yang didapat disimpan dalam jangka panjang. Siswa yang sebelumnya terbiasa melakukan pembelajaran tatap muka akan mengalami kesulitan dalam memahami materi jika siswa tersebut tidak dapat beradaptasi dengan terintegrasinya kegiatan belajar dengan teknologi. Awal pelaksanaan PJJ online, banyak siswa mengeluh sulit memahami materi baik pada pembelajaran secara sinkronus online maupun asinkronus online. Pihak sekolah mengupayakan diadakan seminar online untuk seluruh siswa yang bertujuan untuk memberikan tip-tip sukses belajar online, baik secara konsep pemikiran maupun secara teknis, sehingga membantu siswa beradaptasi saat PJJ online. Bagi siswa yang memang masuk kategori rendah dalam komponen kognitif ini, pihak sekolah berupaya untuk mengundang siswa tersebut ke sekolah untuk memberikan bimbingan teknis secara langsung mengenai teknis bagaimana cara memahami, materi PJJ online yang baik.

Komponen perilaku pada kemampuan self regulation dapat aktivitas seperti tindakan mengatur lingkungan fisik untuk belajar dengan baik, menyiapkan catatan, merekam kegiatan pembelajaran, mendengarkan kembali materi yang sudah direkam, meminimalisasi gangguan saat belajar dan dapat memberi konsekuensi dan penghargaan pada diri sendiri (Schunk, 2011). Kenyataan yang terjadi saat PJJ online adalah siswa belum mampu mengatur diri dalam mengorganisasi hal-hal apa saja yang perlu dilakukan untuk menciptakan kesuksesan belajar. Suatu hal yang sangat penting lainnya saat pelaksanaan PJJ online adalah mengondisikan anggota keluarga seperti adik dan ibunya, karena jika tanpa pengondisian maka adik kecil bisa mengganggu jalannya proses belajar dan begitu juga ibunya yang menyuruh melakukan aktivitas lain seperti membeli sembako di warung, meminta membantu pekerjaan rumah dll. Selain itu kemampuan siswa dalam memonitoring diri sendiri, mengendalikan diri, mengatur perkembangan masing-masing juga perlu 
ditingkatkan agar dapat mencapai tujuan belajar yang diinginkan (Hattie \& Timperley, 2007). Siswa masih sangat perlu bimbingan dalam meningkatkan self regulation pada komponen perilaku ini.

Motivasi adalah komponen self regulation yang berhubungan dengan kepercayaan diri seseorang dalam menentukan pilihan, bertindak dan fokus terhadap usaha untuk menghadapi berbagai tantangan dalam mencapai tujuan yang diinginkan (Schunk, 2011). Harapan seseorang juga akan mempengaruhi tindakan dalam mengatur diri sendiri. Ketika seseorang berharap sukses makan orang tersebut akan mengatur diri untuk menjadi sukses dan sebaliknya jika seseorang tidak memiliki harapan untuk sukses maka orang tersebut akan cepat menyerah dan tidak akan mau berusaha.

Analisis yang telah dilakukan terhadap hasil survey online memberi gambaran bagaimana kemampuan self regulation siswa pada komponen kognitif, perilaku dan motivasi. Kuisioner yang diisi oleh siswa bertujuan untuk mengidentifikasi bagaimana kemampuan self regulation tersebut diimplementasikan pada tiga tahap pelaksanaan PJJ, yaitu tahap persiapan sebelum PJJ online (Preparation), tahap pelaksanaan (Implementation ) dan tahap setelah PJJ online (Reflection). Siswa tidak menerapkan self regulation pada semua tahap tersebut.

Pada tahap sebelum PJJ online (Preparation), siswa menerapkan self regulation pada komponen perilaku dan motivasi saja. Komponen perilaku yang berbentuk upaya menyiapkan dan mengondisikan lingkungan rumah agar kondusif saat belajar online. Sedangkan komponen motivasi berbentuk upaya untuk dapat memotivasi diri agar semangat ketika belajar online yang bentuk kesadaran bahwa belajar adalah salah satu bentuk ibadah.

Pada tahap implementasi siswa menerapkan self regulation pada seluruh komponen. Hal ini dilakukan karena pada tahap ini siswa harus dapat mengatur, memonitoring dan mengevaluasi diri agar dapat memahami materi dan menyelesaikan tugas-tugas dengan baik. Begitu juga pada tahap setelah PJJ online, siswa menerapkan self regulation pada seluruh komponen. Meskipun pembelajaran secara online telah berakhir, siswa harus dapat meregulasi diri untuk memahami materi yang belum dipahami atau akan diperdalam serta perilaku disiplin dalam mengumpulkan tugas. Komponen motivasi menjadi hal yang sangat penting pada tahap ini.

Self regulation berkaitan dengan kemampuan meregulasi diri, kinerja tugas dan tujuan yang akan dicapai (Zheng et al., 2020). $\mathrm{Hal}$ ini berarti bahwa implementasi kemampuan self regulation harus dilaksanakan pada waktu yang tepat sesuai dengan kondisi dan situasi yang ada. Pada tahap preparation, implementation dan reflection, sebagian besar siswa berada pada kategori sedang, sehingga siswa memang membutuhkan bimbingan untuk dapat meningkatkan kemampuan mengimplementasikan kemampuan self regulation pada tahap yang tepat. Hal ini menggambarkan bahwa, siswa belum konsisten menerapkan kemampuan Self Regulation.

\section{PENUTUP}

Kesimpulan yang diperoleh dari hasil penelitian ini adalah sebagian besar siswa memilki tingkat kemampuan self regulation pada kategori sedang. Sedangkan jika dianalisis lebih mendalam berdasarkan masing-masing komponen self regulation (kognitif, perilaku dan motivasi), maka sebagian besar siswa juga berada pada kategori sedang. Untuk penerapan self regulation pada periode preparation, implementation dan reflection, juga berada pada kategori sedang. Hasil analisis ini akan menjadi rujukan upaya peningkatan self regulation pada siswa, sehingga siswa dapat lebih beradaptasi dengan PJJ online di era pandemi covid-19 dan juga dapat meningkatkan hasil belajar sesuai dengan tujuan yang diharapkan.

\section{UCAPAN TERIMA KASIH}

Terima kasih kepada Bapak/lbu dosen Sekolah Pascasarjana Universitas Pakuan Bogor yang telah membantu proses penelitian, terima kasih kepada tim manajemen SMA Islam Terpadu Mentari IImu Karawang yang telah mendukung proses penelitian dan siswa SMA Islam Terpadu Mentari ilmu Karawang yang turut berpartisipasi dalam penelitian ini. 


\section{REFERENSI}

Ahorsu, D. K., Lin, C. Y., Imani, V., Saffari, M., Griffiths, M. D., \& Pakpour, A. H. (2020). The Fear of COVID-19 Scale: Development and Initial Validation. International Journal of Mental Health and Addiction. https://doi.org/10.1007/s11469-020-002708

Andrade, H. L., \& Heritage, M. (2017). Using Formative Assessment to Enhance Learning, Achievement, and Academic Self-Regulation. Using Formative Assessment to Enhance Learning, Achievement, and Academic SelfRegulation. https://doi .org/10.4 324/978 1315623856

Blaschke, L. M. (2014). Using social media to engage and develop the online learner in self-determined learning. Research in Learning Technology, 22(February). https://doi.org/10.3402/rlt.v22.21635

Brooks, C., Carroll, A., Gillies, R. M., Hattie, J., \& Gillies, R. (2019). A Matrix of Feedback for Learning. 44(4).

Caird, S. P., \& Hallett, S. H. (2019). Towards evaluation design for smart city development. Journal of Urban Design, 24(2), 188-209.https://doi.org/10.108 0/1 3574809.2018.1469402

Daniel, S. J. (2020). Education and the COVID19 pandemic. Prospects, (0123456789). https://doi.org/10.1007/s11125-020-094643

Daniela, P. (2015). The Relationship Between Self-Regulation, Motivation And Performance At Secondary School Students. Procedia - Social and Behavioral Sciences, 191, 2549-2553. https://doi. org/10.1016/j.sbspro.2015.04.410

Elleithy, K., \& Sobh, T. (2014). Khaled Elleithy Tarek Sobh.

Golitsyna, I. (2017). Educational Process in Electronic Information-educational Environment. Procedia - Social and Behavioral Sciences, 237(June 2016), 939-944. https://doi.org/10.1016/ j.sbspro. 2017.02.132

Hattie, J., \& Timperley, H. (2007). The Power of Feedback. 77(1), 81-112. https://doi.org/10 .3102/003465430298487

Hooshyar, D., Kori, K., Pedaste, M., \& Bardone, E. (2019). The potential of open learner models to promote active thinking by enhancing self-regulated learning in online higher education learning environments. British Journal of Educational Technology, 50(5), 2365-2386. https://doi.org/ 10.1111/ bjet. 12826

Kuo, Y.-C., Tseng, H., \& Kuo, Y.-T. (2020). Internet Self-Efficacy, Self-Regulation, and Student Performance: African-American Adult Students in Online Learning. International Journal on E-Learning, 19(2), 161-180. Retrieved from http://www.aace. org/pubs/ijel

Lin, J. W., Huang, H. H., \& Chuang, Y. S. (2015). The impacts of network centrality and selfregulation on an e-learning environment with the support of social network awareness. British Journal of Educational Technology, 46(1), 32-44. https://doi.org/ 10.1111/bjet.12120

Odinokaya, M., Krepkaia, T., Karpovich, I., \& Ivanova, T. (2019). Self-regulation as a basic element of the professional culture of engineers. Education Sciences, 9(3). https://doi.org/10.3390/educsci9030200

Pan, X. Ben. (2020). Application of personaloriented digital technology in preventing transmission of COVID-19, China. Irish Journal of Medical Science, 189(4), 11451146. https://doi.org/10.1007/s11845-02002215-5

Runhaar, P., Wagenaar, K., Wesselink, R., \& Runhaar, H. (2019). Encouraging Students' Pro-environmental Behaviour: Examining the Interplay Between Student Characteristics and the Situational Strength of Schools. Journal of Education for Sustainable Development, 13(1), 45-66. https://doi.org/10.1177/097340821984054 4

Sahronih, S., Purwanto, A., \& Sumantri, M. S. (2019). The effect of interactive learning media on students' science learning outcomes. ACM International Conference Proceeding Series, Part F148391, 20-24. https://doi.org/10.1145/3323771.3323797

Salzberger, B., Glück, T., \& Ehrenstein, B. (2020). Successful containment of COVID19: the WHO-Report on the COVID-19 outbreak in China. Infection, 48(2), 151153. https://doi.org/10.1007/s15010-02001409-4

Schraw, G., Crippen, K. J., \& Hartley, K. (2006). Promoting self-regulation in science education: Metacognition as part of a broader perspective on learning. Research 
in Science Education, 36(1-2), 111-139. https://doi.org/10.1007/s11165-005-3917-8

Schunk, D. H. (2011). Handbook of SelfRegulation of Learning and Performance. In Handbook of Self-Regulation of Learning and Performance. https://doi.org/10 $.4324 / 9780203839010$

Sutter, D., \& Smith, D. J. (2017). Coordination in disaster: Nonprice learning and the allocation of resources after natural disasters. Review of Austrian Economics, 30(4), 469-492. https://doi.org/10 .1007/ s11138-016-0369-5

Tian, S., Hu, N., Lou, J., Chen, K., Kang, X., Xiang, Z., ... Zhang, J. (2020). Characteristics of COVID-19 infection in Beijing. Journal of Infection, 80(4), 401406.https://doi.org/10.1016/.jinf.2020.02.01 8

Xie, K., Hensley, L. C., Law, V., \& Sun, Z. (2019). Self-regulation as a function of perceived leadership and cohesion in small group online collaborative learning. British Journal of Educational Technology, 50(1), 456468. https://doi.org/10.1111/bjet.12594

Zaka, P. (2013). A case study of blended teaching and learning in a New Zealand secondary school, using an ecological framework. Journal of Open, Flexible, and Distance Learning, 17(1), 24-40.

Zheng, J., Xing, W., Zhu, G., Chen, G., Zhao, H., \& Xie, C. (2020). Profiling self-regulation behaviors in STEM learning of engineering design. Computers and Education, 143(April 2019), 103669. https://doi.org/ 10.1016/j.compedu.2019.103669 